Copyright (C) 2019 by Academic Publishing House Researcher

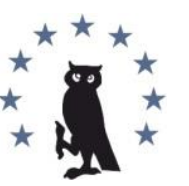

Published in the Russian Federation

European Researcher. Series A

Has been issued since 2010.

E-ISSN 2224-0136

2019, 10(1): 16-26

DOI: 10.13187/er.2019.1.16

www.erjournal.ru

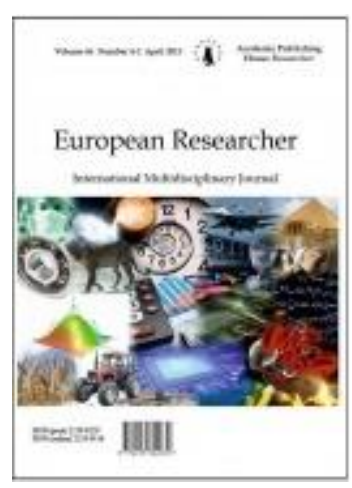

\title{
Hermeneutical Analysis of Feature Films of English-Speaking Countries on the Schools' Theme
}

\author{
Irina Chelysheva ${ }^{a}, *$ \\ a Rostov State Economic University, Russian Federation
}

\begin{abstract}
The topic of the school is presented, including the nature of the relationship between teachers and students, the formation of the identity of schoolchildren, changes in attitudes and representations of characters et all stages of the evolution of the English-language cinema. Social, political, socio-cultural events of the corresponding era are reflected in feature films Teachers and schoolchildren have typical film image stereotypes: a good/bad guy, a beauty, a villain, an intellectual, a loser, a superhero, etc.

Defenders of socially unprotected students dominate in the film images of teachers of the second half of the twentieth century. Then, more and more often, the screen present discussion image of the teacher, who often does not find a common language with students or their parents, using non-pedagogical means to achieve their professional goals. This is often reflected in his vocabulary, appearance, and manners of communication. The genre specificity of English-language films about school subjects has also substantially expanded. The comedy, melodrama and drama were dominated in the early stages of the development of cinema about school and university, but later the ribbons of this subject occupied the entire genre niche, including musicals, horror films, thrillers, science fiction, etc. The topic of social formation was gradually supplemented with stories about the love affairs of schoolchildren and teachers. Many film about school and university included the episodes of violence, cruelty, crime, racial discrimination, drug use, a realistic depiction of erotic scenes.
\end{abstract}

Keywords: hermeneutics analysis, media text, media criticism, USA, UK, English-language film, schoolchildren, characters, image, media education.

\section{1. Введение}

Наше исследование посвящено герменевтическому анализу (включая: анализ стереотипов, идеологический анализ, идентификационный анализ, иконографический анализ, сюжетный анализ, анализ характеров персонажей, гендерный анализ и др.) игровых фильмов англоязычных стран по школьной тематике.

Кинематограф неизменно остается одним из главных медийных искусств, «эффективным средством влияния (в том числе и политического, идеологического) на аудиторию» (Федоров, 2013: 5). Исследование основных структурных компонентов игровых англоязычных аудиовизуальных медиатекстов представляет собой актуальную проблему исследования, так как выступает важным сегментом генезиса мировых медиаискусств.

\footnotetext{
${ }^{*}$ Corresponding author

E-mail addresses: ivchelysheva@yandex.ru (I. Chelysheva)
} 
В связи с тем, что «смена парадигмы в кино предполагает изменение модели мышления, которая влечет за собой изменение ценностей, метода и технических средств создания фильма, равно как и преобразование киноэстетики» (Артюх, 2010).

Данное исследование носит междисциплинарный характер, так как проблематика фильмов школьной тематики выступает предметом изучения медиакритики, искусствоведения, теории и истории культуры, медиаобразования.

\section{2. Материалы и методы}

Основным материалом настоящего исследования выступают англоязычные игровые фильмы школьной тематики, а также научные труды отечественных и зарубежных исследователей. Методы исследования: герменевтический анализ медиатекстов, сравнение и классификация, описательно-аналитические и историографические методы. Базовыми векторами герменевтического анализа англоязычных игровых фильмов выступают исследования К. Бэзэлгэт (Bazalgette, 1995), А. Силверблэта (Silverblatt, 2001), У. Эко (Эко, 1998; 2005), в которых за основу анализа аудиовизуальных медиатекстов положены такие ключевые понятия медиаобразования как «медийные агентства» (media agencies), «категории медиа/медиатекстов» (media/media text categories), «медийные технологии» (media technologies), «языки медиа» (media languages), «медийные репрезентации» (media representations), «медийные аудитории» (media audiences).

\section{3. Обсуждение}

Проблематика англоязычных фильмов о школе представлена в работах отечественных и зарубежных исследователей (Грибанова, 2017; Жарикова, 2015; Масленникова, 2015; Соловьев, 2012; Джеймс, 2002; Brown 2011, 2015; Trier, 2000; 2001 и др.).

В диссертационном исследовании В.В. Жариковой представлен сравнительный анализ тематико-жанровой специфики игровых фильмов, созданных в России и США в историкоискусствоведческом контексте. Так, автором выделяется понятие хронотопа подросткового мира, характерного для американского игрового кинематографа: «Подростковый мир состоит как из определенных переживаний, ситуаций, конфликтов, так и из вполне конкретных пространств: - школа, дом, а также места отдыха и развлечений, несанкционированные взрослыми (заброшенное здание, пустырь и т.д.), места увеселений, специально ориентированные на молодежь (дискотека, клуб, домашняя вечеринка). Именно соединение этих аспектов - определенного мира и самоощущения с положением, как в пространстве, так и в социуме, и в историческом времени - порождают хронотоп молодежного мира, каким он предстает в литературе и кинематографе» (Жарикова, 2015: 10-11).

В.В. Жариковой выделены несколько этапов, определяющих специфику фильмов о подростковой аудитории, среди которых выделяется период 30-40-х годов XX века, где подростковая трансформация в киноповествовании развивается по двум направлениям. Первое из них заключается в следующем: «пройдя испытание (любовью, дружбой или ответственностью), герой возвращается в свое исходное положение жизнерадостного и зависимого подростка. В рамках этого направления утверждается необходимость существования «этого особенного возраста» для успешного функционирования всего социума, чтобы стать взрослым, нужно побыть веселым, глуповатым и безответственным подростком» (Жарикова, 2015: 47). Во втором случае жизнь героев школьного возраста кардинально меняется под воздействием процесса перевоспитания, когда «встреча с ответственным, понимающим и сильным духом взрослым предотвращает превращение несовершеннолетних героев в преступников» (Жарикова, 2015: 47).

Кстати, данная тема игрового кино школьной тематики также была одной из ключевых в советском игровом кино в 30-е - 60-е годы XX века (Челышева, 2018). Примером тому могут служить советские фильмы «Путёвка в жизнь» (1931), «Педагогическая поэма» (1955), «Флаги на башнях» (1958), «Республика ШКИД» (1966) и др. Нужно сказать, что основополагающую роль в процессе перевоспитания в англоязычных и российских кинолентах на этом этапе играют взрослые: учителя и воспитатели.

Нужно отметить, что фигура учителя/педагога/директора школы продолжает оставаться доминирующей и на более позднем этапе развития англоязычного игрового 
кинематографа школьной тематики в 50-е годы XX века. Она представлена в фильмах на тему школы драматического и комедийного жанров: «Школьные дни Тома Брауна» (1951), «Её двенадцать мужчин» (1954), «Школьные джунгли» (1955), «С добрым утором, мисс Дав» (1955), «Наша мисс Брукс» (1957), «Школа: конфиденциально!» (1958) и др. Иными словами, «формула перевоспитания в рамках институции (школы, интерната) в данный период приобретает законченную форму, в центре которой оказывается фигура учителяреформатора, по сути, являющегося главным героем в рамках данной драматургической модели» (Жарикова, 2015: 54).

6о-е годы XX столетия вошли в историю англоязычного кинематографа как период активного формирования и позже - «кризиса молодежной контркультуры» (Жарикова, 2015: 57). Острые проблемы подрастающего поколения, связанные с социальными проблемами, поиском своего места в жизни, первой любви и т.п. находили отражение и в фильмах школьной проблематики. Вместе с тем, в фильмах данного периода затрагивались не только проблемы в жизни учеников, но и учителей: «Детский час» (1961), «Роскошество в траве» (1961), «Сотворившая чудо» (1962), «Вверх по лестнице, ведущей вниз» (1967), «Учителю с любовью» (1967), «Школьные дни Тома Брауна» (1971) и др.

Рассматривая феномен развития американского кинематографа 1960-х, Д. Джеймс указывает на формирование особой картины мира, создаваемой на экранах, отражавшей социальные, культурная, политические перемены и события: поколение битников, «Студенты за демократическое общество», «Гражданские права» и «Власть черным», хиппи и контркультура, война во Вьетнаме, Уэзермены, «Новая мораль» и движение за женское равноправие - вот лишь некоторые из влиятельных течений и социальных феноменов в США, возникших как результат многообразного, постоянно меняющегося, беспрерывного процесса политической и культурной активности. Эти социальные контестации заявляли о себе на всех уровнях - от индивидуального сознания до политической структуры как внутри страны, так и за ее пределами» (Джеймс, 2002).

Понятно, что все эти события, так или иначе, находили свое отражение в игровых фильмах школьной тематики. Так, например, темы отношения к политике ярко представлены в фильме «Расцвет мисс Джин Броди» (1969). Темы расовой дискриминации, преступности, насилия и жестокости также отражались в англоязычных игровых фильмах («Школьницы-правонарушители», 1975; «Площадка для игр дьявола, 1976; «Резня в школе», 1976; «Зачем стрелять в учителя?», 1977 и др.)

Школьная проблематика в игровом кинематографе рассматривается и в исследовании О.Н. Масленниковой, рассматривающей образы учителей/преподавателей в отечественном и зарубежном кино. В результате автор приходит к выводу о том, что на разных периодах развития кинематографического искусства «поэтика образа преподавателя/учителя если и претерпела изменения согласно времени и внешней атрибуции, то в сущностном измерении оставила главное: в каком-то смысле воспроизводимые современным поколением кинообразы желаемого учителя/преподавателя оказываются по ту сторону «ума»: они оказываются вне системы, вне рамок, не боятся быть другими, странными, идут «путем не легким, но благородным» (Масленникова, 2015).

В работе Н.Е. Грибановой, посвященной изучению англоязычных фильмов в работе с будущими педагогами отмечается, что для современного американского кинематографа, в отличие от многих отечественных игровых фильмов, образ школьного учителя представлен более оптимистично: «сняты не только сатирические или мрачные, но и оптимистичные картины о данной профессии. Учитель в американских фильмах не всегда показан идеальным, но он способен расти и совершенствоваться» (Грибанова, 2017). В качестве примеров автор приводит снискавших любовь и уважение своих учеников киногероев: строгого учителя истории в престижной Академии - героя фильма «Императорский клуб» (США, 2002); вдумчивой и независимой преподавательницы истории искусств Кэтрин Энн Уотсон из «Улыбки Моны Лизы» (США, 2003). Что касается изображения школьников на игровом киноэкране, то здесь автором отмечается весьма пестрая картина персонажей «от озлобленных детей из неблагополучных семей и криминальных районов до самоуверенных отпрысков высокопоставленных родителей» (Грибанова, 2017).

Пальма первенства по количеству англоязычных фильмов, снятых по школьной проблематике, принадлежит американскому кинематографу. На современном этапе, как 
считает А.И. Соловьев, в американском кино можно увидеть два типа учителей: «строгие пуритане, держащие своих учеником в постоянном страхе, и успешные, веселые красавцы, которых в их работе не отягощает ничто, даже священный долг учить, наставлять, воспитывать» (Соловьев, 2012). Консервативные учителя «применяют устаревшие методы обучения, авторитарны, комичны, старомодны, неустроенны, достойны жалости. При этом показаны и молодые педагоги-новаторы, готовые поддержать даже сексуальную революцию. Таким образом, в современном западном кинематографе драматические или даже трагические фильмы на школьную тематику мирно уживаются с более многочисленными комедийными фильмами и сериалами, которые можно разделить на молодежные и взрослые (Соловьев, 2012).

В исследованиях Т. Брауна (Brown, 2011; 2015) представлен развернутый анализ репрезентации социальных ролей учителя на разных этапах развития кино. Автором выделяется несколько основных ролей учителя в фильмах школьной тематики, среди которых: всеми уважаемый и мудрый педагог-интеллектуал, о котором повествуют фильмы школьной тематики 1930-х - 1940-х годов; строгий, но справедливый наставник трудных и не всегда послушных школьников, представленный на экранах 1950-х; героический, самоотверженный учитель-спаситель обездоленных и бедных, отстаивающий свои принципы и взгляды, в фильмах последних десятилетий XX века.

T. Браун полагает, что практически все XX столетие учитель в фильмах обычно изображается в позитивном свете, и, несмотря на все ошибки, экранный педагог делает все возможное, чтобы помочь своим ученикам в саморазвитии, в стремлении занять достойное место в жизни (Brown, 2015: 4).

Согласно Т. Брауну, в школьных фильмах начала XXI столетия образ учителя существенно трансформируется. Происходит отход от идеализированной модели образа учителя. Одновременно с показом трудностей педагогической профессии зритель встречается с учителем, сталкивающимся с социальными, нравственными и межэтническими проблемами, такой педагог не всегда готов к новым вызовам общества. В начале XXI века учителя всё чаще перестают изображаться на экране как мученики, напротив, нередки образы ленивых и не желающих адаптироваться к новым вызовам общества педагогов. Возникает и еще один образ учителя, работа которого далеко не всегда нацелена на оптимальные модели обучения, напротив, он нередко борется с родителями учащихся, исключая их из процесса принятия решений в отношении образования их детей (Brown, 2015).

Д. Триер (Trier, 2000; 2001) в своих исследованиях представил возможности использования игровых фильмов школьной тематики для развития критического/аналитического мышления. Автором отмечается, что данная категория аудиовизуальных медиатекстов может успешно использоваться в качестве инструмента для применения на занятиях по развитию критического мышления как школьной, так и учительской аудитории. В качестве наиболее продуктивного подхода к осуществлению критического анализа фильмов о школе Дж. Триер (Trier, 2000) предлагает осуществление социального контекста кинолент, изучение научных и популярных критических статей и использование дискуссионных методов, позволяющих обсудить проблемы, затронутые в данных медиатекстах.

\section{4. Результаты}

Англоязычные фильмы на тему школь

Место действия, исторический, социокультурный, политический, идеологический, контекст. Особенности исторического периода создания медиатекстов, условия рынка, которые способствовали замыслу, процессу создания медиатекстов, степень влияния событий того времени на медиатексты

Игровые англоязычные фильмы школьной тематики, так или иначе, отражают социальные, политические, экономические и другие проблемы, происходящих в обществе. Можно выделить несколько основных этапов развития данной темы в англоязычном кинематографе, на каждом из которых представляется свой образ школы в целом, определяющий репрезентацию основных исторических событий, персонажей учителя и учеников, проблемы, с которыми они сталкиваются и т.д. 
Так, например, период немого англоязычного кинематографа (1910-1920 гг.), представленный в основном короткометражными кинолентами («После школы», 1912; «День в школе», 1916; «Школьные дни Тома Брауна», 1916 и др.), характеризуется незамысловатыми сюжетами о школьной жизни, место действия которых во многих случаях ограничивается школьным классом.

Вместе с тем, в англоязычном кинематографе о школе отразился экономический кризис 1920-1930-х годов и затяжная великая депрессия («Герой средней школы, 1927; «Маленькая красная школа», 1936; «Школа для преступников», 1938 и др.). В этот период место действия фильмов вышло за рамки школы, мы видим не только школьные классы, но и улицы, дворы, домашнюю обстановку, где происходят события.

На американских и британских экранах 1950-х нашлось место так называемой «моральной панике» и эксплуатации образа неблагополучного подростка (Жарикова, 2015). Тематика англоязычных фильмов о школе 1960-х коснулась изменений, происходивших в обществе: появление и развитие молодежной контркультуры, протест против существующих порядков (в то числе - и в школе), увлечение философией рок-н-ролла и джаза, трансформация характера первых романтических отношений под влиянием первых проявлений «сексуальной революции» и т.д. Места действий этих фильмов весьма разнообразны: не только школьные классы, учительские и жилища учащихся/педагогов, но и летние лагеря/школы, заброшенные пустыри и стройки и т.п.

Англоязычные фильмы 1970-1980-х продолжали репрезентацию основных тем предыдущего периода. В этих аудиовизуальных медиатекстах было представлено многообразие обстановки действия, включая места учебы, отдыха, развлечений, иногда и с фантастическим уклоном. Ярким примером последнего может служить фантастическая кинотрилогия «Назад в будущее» $(1985,1989,1990)$.

Для англоязычных фильмов о школе более поздних периодов характерно постепенное включение в сюжет объектов виртуальной реальности, характеризующие переход к новому информационному обществу. Теперь школьник - участник уже не только реальных, но и виртуальных событий компьютерных игр, интернет-пространства, которые постепенно начинают оказывать на него все более значимое влияние и порой предопределяют вполне реальные события в жизни и места событий в фильме.

Социокультурный, идеологический, мировоззренческий, религиозный контекст. Идеология, направления, цели, задачи, концепции авторов данных медиатекстов в социокультурном контексте; культура мира, изображенного в медиатекстах.

Вечная тема непреходящих ценностей, таких как любовь, дружба, честность, взаимовыручка, умение противостоять злу и отстаивать добро выступает одной их основных в англоязычных игровых фильмах о школе и вузе.

Наряду с этими темами мировоззренческая позиция героев медиатекстов нередко связана с преодолением различных препятствий (как внешних, так и внутренних), после чего персонаж имеет возможность стать героем (класса, школы, общества в целом). В этом случае признание личных и социальных заслуг персонажа становятся своеобразной культурой мира, где любому человеку, нередко внешне простоватому, ничем не выдающемуся неудачнику, доступны самые трудные вершины и победы.

Религиозный контекст не является доминирующим в игровых фильмах о школе. Вместе с тем отрицания религиозных верований, положительных аспектов веры в англоязычных медиатекстах на школьную тему практически нет, зачастую, персонажи в особо трудные моменты своей жизни обращаются к вере, посещая храм и вознося молитвы о поиске смысла жизни, воссоединении с семьей, улучшении своей жизни.

Мировоззрение персонажей «школьного мира», изображенного в медиатекстах: главной отправной точкой в англоязычных фильмах на тему школы и вуза выступает мечта о счастливой жизни, возможности, которые открываются перед нынешним школьником/студентом, поиск перспектив и жизненных ценностей. И хотя во многих лентах «пространство подросткового мира замкнуто и ограничено - это дом и школа и пространство между ними... но эта замкнутость потенциальна безграничностью, ощущением полноты сил и возможностей, свойственных подростку (так же, как и связанные с этим ощущением страхи)» (Жарикова, 2015: 12). 
Ярким примером здесь может выступать главный герой английского фильма «Школьные дни Тома Брауна» (1951). Том - ученик престижной школы, главной задачей которого становится борьбе с насилием и притеснением, с которыми он сталкивается в очень благополучном, на первый взгляд, учебном заведении. Жизненные ценности и взгляды Тома совпадают с позицией директора школы Томаса Арнольда, который вместе со школьником предпринимает попытки прекратить беспорядки и жестокость в стенах школы.

Структура и приемы повествования в данных медиатекстах

- место и время действия медиатекстов: школы различных типов: от элитных («Школьные дни Тома Брауна», 1951) до исправительных образовательных учреждений («Школа для преступников», 1938), здания (от жилых помещений до заброшенных строек), улица (как многолюдные, так и пустынные улицы), летние лагеря, лужайки, парки.

- характерная для данных медиатекстов обстановка, предметы быта: предметы быта и обстановка персонажей находятся в зависимости от материального благополучия героев. В фильмах школьной тематики ранних периодов превалирует скромная и даже аскетичная обстановка, позже во многих фильмах о школе представлены респектабельные особняки, где живут герои, автомобили, которые имеют не только учителя, но и ученики.

- жанровые модификации школьно-вузовской тематики: на первых этапах развития кинематографа преобладающими жанрами в фильмах школьной тематики выступают комедия, мелодрама и драма. Позже жанровая специфика фильмов рассматриваемой тематики дополняется музыкальными фильмами (мюзиклами), пик популярности которых приходится на 1950-е - 1970-е, фильмами ужасами, триллерами, фантастикой.

- (стереотипные) приемы изображения действительности: как правило, в фильмах школьной тематики наиболее стереотипными персонажами на всех этапах развития игрового кино выступают: положительный и отрицательный лидеры класса; тихоня (неудачник), который(ая) вполне может стать героем; признанная всеми заносчивая красавица и др. Позже нередко в фильмах можно встретить представителей разных этносов, молодежных субкультур, определенных музыкальных течений, фанатов, интеллектуалов/компьютерных гениев.

Типология персонажей (черты характера, одежда, телосложение, лексика, мимика, жесты персонажей, присутствие или отсутствие стереотипной манеры репрезентации персонажей в данных медиатекстах):

- возраст персонажей. Возрастные рамки школьной аудитории соответствуют возрастным нормам, которые в англоязычных фильмах школьной тематики находятся в пределах от 7 до 20 лет. В фильмах 1960-1970-х годов преобладают подростки, в фильмах более поздних периодов - старшеклассники. Большинство учителей достаточно молоды, что придает им энтузиазма и стремления к революционным переменам школьной системы, реформирования существующего порядка в ведении уроков и во взаимоотношениях учителей и учеников. Причем, данные типажи учителей встречаются практически на всех этапах развития игрового кинематографа о школе. В качестве примера можно рассматривать учительницу Сильвию Барретт из фильма «Вверх по лестнице, ведущей вниз» (1967); Ричарда Дэдьера - учителя из фильма «Школьные джунгли» (1955) и др. любым.

Возраст родителей, членов семьи персонажей и второстепенных героев может быть

- уровень образования: школьники получают образование в стенах школы, учителя далеко не всегда имеют за спиной университет. Нередко в англоязычных фильмах школьной тематики учителя не имеют специального образования, и приходят в школу из других сфер деятельности.

- социальное положение, профессия: в англоязычных фильмах на разных этапах развития игрового кинематографа можно увидеть представителей порой диаметрально противоположных социальных групп школьников. Так, например, в период 1950-х одним из ключевых социальных слоев, представленных на экране, были неблагополучные и бедные, правонарушители («Школа: конфиденциально!», 1958) и др. Позже на экранах США и Великобритании можно было встретить представителей разного социального положения. Родители школьников в англоязычных фильмах занимаются разными видами профессионального труда. Если говорить о семье среднего уровня, то мамы персонажей школьного возраста преимущественно - домохозяйки, заняты воспитанием детей. 
- семейное положение персонажа: чаще всего персонажи школьного возраста показаны в составе большой (нередко многодетной семьи), где есть оба родителя. Что касается учителей, то их семейное положение далеко не всегда бывает устойчивым. Нередко учитель находится не только в творческом поиске профессиональных средств обучения, но и в поиске (далеко не всегда успешном) спутника жизни.

- внешний вид, одежда, телосложение персонажей, черты их характеров, лексика: внешний вид учителей и учеников в фильмах о школе первой половины XX столетия подтянутый, опрятный, строгий. Позже внешний вид учителя и ученика становится более свободным, нередко даже ярким или вызывающим.

Черты характеров учителей и учеников могут быть совершенно разными: от тихого и скромного персонажа 1930-1940-х до раскрепощенного и независимого от мнения общества человека в фильмах более поздних периодов.

Лексика учеников в фильмах далеко не всегда отличается высоким уровнем культуры. Особенно это касается фильмов о малолетних правонарушителях или девиантных подростках. Хотя и в фильмах, которые повествуют о жизни обычных и даже престижных школ, нередко можно услышать фривольные и грубые выражения, даже по отношению к учителям и родителям. В лексике руководящего состава школы нередко прослеживаются бюрократические нотки: требования придерживаться циркуляров, обязанности следить за тем, чтобы занавеси в классе находились на строго отмеренной высоте четырех дюймов, постоянный контроль за ученическими карточками, хранение документации в алфавитом порядке и т.д.

Обычные учителя, предстающие умными и эрудированными людьми, в англоязычных аудиовизуальных медиатекстах постепенно утрачивают строгие каноны разговорной речи, да и поведения. В их лексике нередко можно услышать жаргонные выражения и грубые слова, в том числе - в адрес учеников.

Существенное изменение в жизни персонажей медиатекстов и возникиая проблема (нарушение привычной жизни):

Вариант № 1 (ученический):

- превращение школьника, который, на первый взгляд, кажется наивным недотепой или неудачником, в супергероя;

- изменение внутреннего мира, мировоззрения героя после определенных событий;

- противостояние персонажа-школьника насилию, жестокости, притеснениям.

Вариант № 2 (педагогический): поиск методов, средств и приемов для: наиболее оптимальной модели взаимодействия с учениками; позитивных изменений в личной жизни.

Решение проблемы:

Вариант № 1 (ученический):

Существенное изменение в жизни персонажей происходит под воздействием перевоспитания или в результате пройденных испытаний (порой смертельно опасных). И если в фильмах первой половины XX столетия доминирующим фактором выступает мудрое руководство формированием личности школьников учителем, старшим товарищем или воспитателем (как, например, в фильме «Школа для преступников», 1939), то во второй половине XX столетия роль воспитателя и учителя школьника отдается самой жизни. Под воздействием определенных обстоятельств (иногда весьма фантастических), школьник сам начинает понимать, каким ему следует стать, чтобы быть успешным, умным, самостоятельным, как в известной трилогии «Назад в будущее» $(1985,1989,1990)$.

Вариант № 2 (педагогический): педагог находит необходимый подход к ученикам, находит личное счастье; под воздействием событий учитель разочаровывается/становится равнодушным.

\section{5. Заключение}

Итак, проведенный герменевтический анализ англоязычных игровых фильмов школьной тематики позволил нам сделать следующие выводы.

На всех этапах эволюции игрового кинематографа представлена тема школы, включая характер взаимоотношения учителей и учеников, становления личности школьников, изменения мировоззренческих установок и представлений персонажей и т.д. В англоязычных фильмах находят отражение социальные, политические, социокультурные 
события соответствующей эпохи. Как кинообразы учителей, так и кинообразы школьников имеют стереотипы, характерные для большинства аудиовизуальных медиатекстов массовой культуры: хороший/плохой парень, красавица, злодей, интеллектуал, неудачник, супергерой и т.д.

Если провести сравнительную характеристику англоязычных и русскоязычных фильмов школьной тематики (Челышева, 2018), снятых на разных этапах развития кинематографа, то можно выделить целый ряд сходных тенденций репрезентации образа учителей и учеников в экранных произведениях. Так, например, известно, что одним из типичных сюжетов в советских фильмах о школе 1920-1930-х годов выступала тема беспризорников, которые в результате приобщения к новым ценностям (труду, вступлению в пионеры и т.д.), которое осуществляли мудрые и справедливые педагоги, вожатые, становились совершено новыми людьми - истинными борцами, верящими в светлое будущее. Советские фильмы этого периода на тему школы были «пронизаны нравственным пафосом, идеологическими символами, образами и стереотипами» (Челышева, 2018). Англоязычные фильмы того времени были не столь идеологизированы, однако тема перевоспитания «трудных» учащихся мудрым учителем или иным взрослым персонажем также хорошо заметна. Примером тому может быть американский фильм «Школа для преступников» (1938), где малолетних хулиганов перевоспитывают «герои-мужчины, действующие практически в одиночку. Основными методами перевоспитания становится труд, товарищество и доверие» (Жарикова, 2015: 14).

Образы учителей приобретают к началу второй половины XX века иную окраску: героя, защитника представителей социально незащищенных учеников. Еще позже мы всё чаще видим на экране далеко не идеальный образ учителя, нередко не находящего общего языка ни с учениками, ни с их родителями, использующего далеко не педагогические средства для достижения своих профессиональных целей. Это нередко отражается и в его лексике, внешнем виде, манерах общаться.

Жанровая специфика англоязычных фильмов школьной тематики также существенно расширилась. Если на первых этапах развития игрового кинематографа фильмы о школьной жизни ограничивались комедийными, мелодраматическими и драматическими и комедийными сюжетами, то позже ленты данной тематики заняли всю жанровую нишу, включая мюзиклы, фильмы ужасов, триллеры, фантастику и т.д. К темам социального становления постепенно добавились сюжеты о любовных отношениях школьников и учителей. В центре многих киносюжетов о школе и вузе становится насилие, жестокость, преступность, расовая дискриминация, употребление наркотиков, реалистическое изображение эротических сцен и др. Это можно проследить как в общей концепции фильмов, так и в репрезентации образов основных и второстепенных линий сюжета.

\section{6. Благодарности}

Статья написана в рамках исследования при финансовой поддержке гранта Российского научного фонда (РНФ). Проект № 17-18-01001 «Школа и вуз в зеркале советских, российских и западных аудиовизуальных медиатекстов», выполняемый в Ростовском государственном экономическом университете.

\section{Литература}

Артюх, 2010 - Артюх, A.A. Смена парадигмы развития киноискусства и киноиндустрии США. Дис. ... д-ра искусствоведения. СПб., 2010. 182 с.

Грибанова, 2017 - Грибанова, H.E. Фильмы об учителях на английском языке как средство образования будущих педагогов // Филологические науки. Вопросы теории u практики. 2017. № 7 (73). Ч. 1. С. 188-190. [Электронный pecypc]. URL: https://cyberleninka.ru/article/n/filmy-ob-uchitelyah-na-angliyskom-yazyke-kak-sredstvoobrazovaniya-buduschih-pedagogov

Джеймс, 2002 - Джеймс, Д. Аллегории кино: американский кинематограф шестидесятых // Киноведческие записки. 2002. № 60. [Электронный ресурс]. URL: http://www.kinozapiski.ru/ru/article/sendvalues/197/

Жарикова, 2015 - Жарикова, B.В. Тематико-жанровая структура молодежного фильма (на примере американского и отечественного кино 1930-х - 1980-х годов). Автореф. ... дис. 
канд. искусствоведения. M., 2015. [Электронный ресурc]. URL: http://www.dslib.net/kinoiskusstvo/tematiko-zhanrovaja-struktura-molodezhnogo-filma.html\#7537531

Масленникова, 2016 - Масленникова, О.Н. Поэтика образа: «безумные преподы» в кинематографе // Kunst камера: искусство кино и межкультурный диалог / Тезисы научной конференции 14-16 ноября 2016 г. СПб.: СПГУ, 2016. С. 58-59.

Соловьев, 2012 - Соловъев, А.И. Образ учителя в кино: Запад versus Восток. СМИ и современная культура. Минск: БГУ, 2012. [Электронный pecypc]. URL: http://docplayer.ru/28752238-Obraz-uchitelya-v-kino-zapad-versus-vostok.html

Федоров, 2013 - Федоров, А.В. Трансформации образа России на западном экране: от эпохи идеологической конфронтации (1946-1991) до современного этапа (1992-2010). М.: Изд-во МОО «Информация для всех», 2013. 230 с.

Челышева, 2018 - Челышева, И.В. Анализ философских, антропологических подходов к теме школы в советских и российских аудиовизуальных медиатекстах (на материале игрового кино) // Alma Mater. Вестник высшей школы. 2018. № 1. С. 109-115.

Эко, 1998 - Эко У. Отсутствующая структура. Введение в семиологию. СПб.: Петрополис, 1998. 432 с.

Эко, 2005 - Эко У. Роль читателя. Исследования по семиотике текста. СПб: Симпозиум, 2005. $502 \mathrm{c}$.

Bazalgette, 1995 - Bazalgette, C. Key Aspects of Media Education. Moscow: Association for Film Education, 1995 .

Brown, 2011 - Brown, T. Using film in teaching and learning about changing societies. International Journal of Lifelong Education, 2011, 30 (2), 233-247.

Brown, 2015 - Brown, T. Teachers on film: changing representations of teaching in popular cinema from Mr. Chips to Jamie Fitzpatrick. In Jubas, K., Taber, N., Brown, T. Popular Culture as Pedagogy Research in the Field of Adult Education. Rotterdam, 2015.

Chelysheva, 2017 - Chelysheva, I. Hermeneutical analysis of the soviet feature films of the thaw era (1956-1968) on the school theme. European researcher. Series A. 2017. № 8(4), 271-284.

Chelysheva, 2018 -Chelysheva I. Hermeneutic Analysis of Russian Feature Films (19922017) on the School Theme // Zhurnal ministerstva narodnogo prosveshcheniya, 2018, 5(1): 3-15.

Silverblatt, 2001-Silverblatt, A. Media Literacy. Westport, Connecticut - London: Praeger, 2001, 449 p.

Trier, 2000 - Trier, J.D. Using Popular "School Films" To Engage Student Teachers in Critical Reflection. Annual Meeting of the American Educational Research Association. 2000. New Orleans, LA, April, 24-28.

Trier, 2001 - Trier, J.D. The cinematic representation of the personal and professional lives of teachers. Teacher Education Quarterly, 2001. 28 (3), 127-142.

\section{References}

Artyukh, 2010 - Artyukh, A.A. (2010). Smena paradigmy razvitiya kinoiskusstva i kinoindustrii SShA [Change the paradigm of the development of filmmaking and the film industry in the United States]. Dis. ... d-ra iskusstvovedeniya. SPb. 182 p. [in Russian]

Bazalgette, 1995 - Bazalgette, C. (1995). Key Aspects of Media Education. Moscow: Association for Film Education.

Brown, 2011 - Brown, T. (2011). Using film in teaching and learning about changing societies. International Journal of Lifelong Education, 30 (2), 233-247.

Brown, 2015 - Brown, T. (2015). Teachers on film: changing representations of teaching in popular cinema from Mr. Chips to Jamie Fitzpatrick. In Jubas, K., Taber, N., Brown, T. Popular Culture as Pedagogy Research in the Field of Adult Education. Rotterdam.

Chelysheva, 2017 - Chelysheva, I. (2017). Hermeneutical analysis of the soviet feature films of the thaw era (1956-1968) on the school theme. European researcher. Series A, № 8(4), 271-284.

Chelysheva, 2018 - Chelysheva, I.V. (2018). Analiz filosofskikh, antropologicheskikh podkhodov $\mathrm{k}$ teme shkoly $\mathrm{v}$ sovetskikh i rossiiskikh audiovizual'nykh mediatekstakh (na materiale igrovogo kino) [Analysis of philosophical, anthropological approaches to the subject of the school in Soviet and Russian audiovisual media texts (on the material of the feature film)]. Alma Mater. Vestnik vysshei shkoly. № 1. pp. 109-115. [in Russian] 
Chelysheva, 2018 -Chelysheva I. (2018). Hermeneutic Analysis of Russian Feature Films (1992-2017) on the School Theme. Zhurnal ministerstva narodnogo prosveshcheniya, 5(1): 3-15.

Dzheims, 2002 - Dzheims, D. (2002). Allegorii kino: amerikanskii kinematograf shestidesyatykh [Allegory of cinema: American cinema of the sixties]. Kinovedcheskie zapiski. 2002. № 60. [Elektronnyi resurs]. URL: http://www.kinozapiski.ru/ru/article/sendvalues/197/ [in Russian]

Eko, 1998 - Eko, U. (1998). Otsutstvuyushchaya struktura. Vvedenie v semiologiyu [The missing structure. Introduction to Semiology]. SPb.: Petropolis. 432 p. [in Russian]

Eko, 2005 - Eko, U. (2005). Rol' chitatelya. Issledovaniya po semiotike teksta [The role of the reader. Studies on the semiotics of the text]. SPb: Simpozium. 502 p. [in Russian]

Fedorov, 2013 - Fedorov, A.V. (2013). Transformatsii obraza Rossii na zapadnom ekrane: ot epokhi ideologicheskoi konfrontatsii (1946-1991) do sovremennogo etapa (1992-2010) [Transformation of the image of Russia on the western screen: from the era of ideological confrontation (1946-1991) to the present stage (1992-2010)]. M.: Izd-vo MOO «Informatsiya dlya vsekh», 230 p. [in Russian]

Gribanova, 2017 - Gribanova, N.E. (2017). Fil'my ob uchitelyakh na angliiskom yazyke kak sredstvo obrazovaniya budushchikh pedagogov [Films about teachers in English as a means of educating future teachers]. Filologicheskie nauki. Voprosy teorii i praktiki. № 7 (73). Ch. 1. pp. 188-190. [Elektronnyi resurs]. URL: https://cyberleninka.ru/article/n/filmy-ob-uchitelyah-naangliyskom-yazyke-kak-sredstvo-obrazovaniya-buduschih-pedagogov [in Russian]

Maslennikova, 2016 - Maslennikova, O.N. (2016). Poetika obraza: «bezumnye prepody» v kinematografe [Poetics of the image: "mad teachings" in the cinema]. Kunst kamera: iskusstvo kino i mezhkul'turnyi dialog. Tezisy nauchnoi konferentsii 14-16 noyabrya 2016 g. SPb.: SPGU, pp. 5859. [in Russian]

Silverblatt, 2001-Silverblatt, A. (2001). Media Literacy. Westport, Connecticut - London: Praeger, $449 \mathrm{p}$.

Solov'ev, 2012 - Solov'ev, A.I. (2012). Obraz uchitelya v kino: Zapad versus Vostok. SMI i sovremennaya kul'tura [The image of the teacher at the cinema: West versus East]. Minsk: BGU, 2012. [Elektronnyi resurs]. URL: http://docplayer.ru/28752238-Obraz-uchitelya-v-kino-zapadversus-vostok.html [in Russian]

Trier, 2000 - Trier, J.D. (2000). Using Popular "School Films" To Engage Student Teachers in Critical Reflection. Annual Meeting of the American Educational Research Association. New Orleans, LA, April, 24-28.

Trier, 2001 - Trier, J.D. (2001). The cinematic representation of the personal and professional lives of teachers. Teacher Education Quarterly, 28 (3), 127-142.

Zharikova, 2015 - Zharikova, V.V. (2015). Tematiko-zhanrovaya struktura molodezhnogo fil'ma (na primere amerikanskogo i otechestvennogo kino 1930-kh - 1980-kh godov) [The thematic-genre structure of the youth film (on the example of American and Russian cinema of the 1930s-1980s)]. Avtoref. ... dis. kand. iskusstvovedeniya. M. [Elektronnyi resurs]. URL: http://www.dslib.net/kino-iskusstvo/tematiko-zhanrovaja-struktura-molodezhnogofilma.html\#7537531 [in Russian]

\section{Герменевтический анализ игровых фильмов англоязычных стран на тему школы}

Ирина Челышева ${ }^{\text {, * }}$

а Ростовский государственный экономический университет, Российская Федерация

Аннотация. На всех этапах эволюции игрового кинематографа представлена тема школы, включая характер взаимоотношения учителей и учеников, становления личности школьников, изменения мировоззренческих установок и представлений персонажей и т.д.

\footnotetext{
${ }^{*}$ Корреспондирующий автор

Адреса электронной почты: ivchelysheva@yandex.ru (И. Челышева)
} 
В англоязычных фильмах находят отражение социальные, политические, социокультурные события соответствующей эпохи. Как кинообразы учителей, так и кинообразы школьников имеют стереотипы, характерные для большинства аудиовизуальных медиатекстов массовой культуры: хороший/плохой парень, красавица, злодей, интеллектуал, неудачник, супергерой и т.д.

В образах учителей второй половины XX века доминируют защитники представителей социально незащищенных учеников. Затем всё чаще на экране возникает далеко не идеальный образ учителя, нередко не находящего общего языка ни с учениками, ни с их родителями, использующего далеко не педагогические средства для достижения своих профессиональных целей. Это нередко отражается и в его лексике, внешнем виде, манерах общаться. Жанровая специфика англоязычных фильмов школьной тематики также существенно расширилась. Если на первых этапах развития игрового кинематографа фильмы о школьной жизни ограничивались комедийными, мелодраматическими и драматическими и комедийными сюжетами, то позже ленты данной тематики заняли всю жанровую нишу, включая мюзиклы, фильмы ужасов, триллеры, фантастику и т.д. К темам социального становления постепенно добавились сюжеты о любовных отношениях школьников и учителей. В центре многих киносюжетов о школе и вузе становится насилие, жестокость, преступность, расовая дискриминация, употребление наркотиков, реалистическое изображение эротических сцен и др. Это можно проследить как в общей концепции фильмов, так и в репрезентации образов основных и второстепенных линий сюжета.

Ключевые слова: герменевтический анализ, медиатекст, медиакритика, США, Великобритания, игровой англоязычный фильм, школьники, персонажи, образ. 